\title{
Clinical Scoring for Distinction of Bacterial and Viral Upper Respiratory Tract Infections of Children
}

\author{
Çocuklarda Viral ve Bakteriyel Üst Solunum Yolları Enfeksiyonlarının Ayırımında Klinik Skorlama

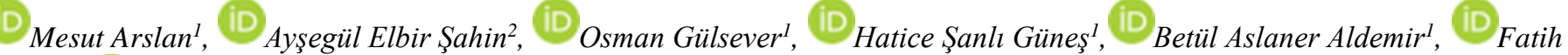 \\ Duran $^{1}$, ID Irfan Ŏguz Şahin ${ }^{1}$
}

${ }^{1}$ Cumhuriyet Üniversitesi Tıp Fakültesi Çocuk Sağlığı ve Hastalıkları Ana Bilim Dalı, Sivas, Türkiye

${ }^{2}$ Sivas Devlet Hastanesi Anesteziyoloji ve Reanimasyon Kliniği, Sivas, Türkiye

\section{ÖZET}

Giriş: Üst solunum yolu enfeksiyonları (ÜSYE) çocuklarda en sık karşılaşılan enfeksiyonlardır. Çalışmamızın amacı ÜSYE için klinik bir skorlama geliştirerek viral-bakteriyel ayrımını yapabilmektir.

Yöntem: Bu çalışma ÜSYE tanısı konulan 5-15 yaşları arasındaki 220 hastada yapıldı. Çalışmamızda incelenececek belirti ve bulguların tespit edilmesi için klinik skorlama ile bakteriyel ve bakteriyel olmayan ÜSYE ayırımını yapmayı hedefleyen önceki çalışmalar gözden geçirildi. Bu belirti, bulgu ve boğaz kültürü sonuçları kayıt altına alındı.

Bulgular: Boğaz kültürlerinde 93 hastada (\%42) üreme oldu. Bu klinik skorlamaya göre ateş, ağrılı anterior servikal lenfadenopati, öksürük olmaması, tonsiller hipertrofi enfeksiyonun bakteriyel olduğunu düşündürmesi açısından istatistiksel olarak anlamlı bulunmuştur. Yutma güçlüğü, karın ağrısı, baş ağrısı, konjoktivit olmaması, ses kısıklığının olmaması, diyare olmaması, istatistiksel olarak anlamsiz bulundu.

Sonuç: Toplam skor kültür ilişkisine göre, toplam skor 7 ve üzerinde ise sonuç anlamlı kabul edilebilir. Çalışmamızda parametrelerin çokluğu, sensitivite ve spesifitenin düşük olması nedeniyle etkin bir skorlama geliştirilemedi.

Anahtar Kelimeler: Üst Solunum Yolu Enfeksiyonu, Çocuk, Skorlama Sistemi

\begin{abstract}
Introduction: Upper respiratory tract infections (URTI) are the most common infections of childhood. The purpose of our study is to develop a clinical scoring method to distinguish viral and bacterial infections in the patients who were diagnosed with URTI.

Methods: This study was conducted in pediatric 220 patients with URTI whose ages were between 5 and 15 . The previous studies about clinical scoring of bacterial and nonbacterial URTI were reviewed to determine signs and symptoms to evaluate in our study. These signs, symptoms and throat swab culture results of the patients were recorded.

Results: Throat swab culture were positive at 93 patients (42\%). According to this clinic scoring system; fever, painful anterior servical lymphadenopathy, lack of cough, tonsillar hypertrophy were found to be statistically significant in terms of predicting bacterial infections. Dysphagia, abdominal pain, headache, lack of conjunctivitis, the absence of hoarseness and the absence of diarrhea were found to be statistically insignificant.

Conclusion: Acording to total score - culture relationship, total score 7 and higher could be considered significant. As a result of our study, we could not develop an effective scoring due to the high number of parameters, low sensitivity and specifity.

Key words: Upper Respiratory Tract İnfections, Scoring System, Children
\end{abstract}

Başvuru / Submission: Eylül / Sept 13, 2017

Kabul / Acceptance: Aralık / Dec 04, 2017

Yazışma / Correspondence: Uzm.Dr. Mesut Arslan, Tatvan Devlet Hastanesi Çocuk Sağlığı ve Hastalıkları, Bitlis, Türkiye

Phone number (Business): +90 4348276325

Fax number: +904348276324

E-mail: drmesutarslan@ @otmail.com 


\section{INTRODUCTION}

Antibiotic resistance is emerging as an important public health issue and overuse of antibiotics by physicians has been implicated as contributing to the problem. ${ }^{1}$ One of the most common reasons for visiting a family physician and receiving an antibiotic is an upper respiratory tract infection (URTI). Pharyngeal lymphoid tissues are the strategic components of the first-line defense mechanism against infections in the upper respiratory tract. These immune structures are inactive at the first year of life (due to the maternal antibodies); hypofunctional at 2-3 years of life (due to life in limited and protected areas); hyperfunctional and hypertrophied at 3-9 years of life (due to increased immune stimulus). Infections of pharyngeal lymphoid tissues increase in hypertrophy period. ${ }^{2}$

Upper respiratory tract infections (URTI) are the most frequent infections in childhood. ${ }^{3,4}$ Many agents cause URTI. Group A $\beta$ Hemolytic Streptococci (GABHS) are the most common causes in bacterial agents but viruses are the most common causes. ${ }^{5}$ In the recent decades, the emergence of antibiotic resistance has been raising an alarm in the international stage and precipitating repeated calls for more judicious use of antibiotics. ${ }^{6}$ The exact distinction of viral or bacterial URTIs is fundamental for decreasing unnecessary antibiotic use and prevent antibiotic resistance of bacteria. ${ }^{3}$

Different forms of bacterial/viral URTIs (acute nasopharyngitis, acute otitis media, acute rhynosinüsitis, and acute tonsillofarenjit) present with different combinations of same symptoms (anorexia, myalgia, fever, crying, restlessness, diarrhea, nausea, vomiting, abdominal pain, sore throat, coughing, malaise, headache, pain etc.). This makes difficult to define URTI as viral or bacterial only with clinical evaluation. Therefore, clinicians should need laboratory testing. According to our literature review, a clinical scoring to distinct viral and bacterial URTIs tried to be improved but there is not an approved effective scoring system.

The aim of our study is to improve a simple and effective clinical scoring system to make distinction of viral or bacterial URTI according to symptoms and signs of children without using any laboratory tests.

\section{METHODS}

This prospective study was performed in Pediatrics Department and Pediatric Emergency of Cumhuriyet University Faculty of Medicine between August 2014 and June 2015. Study was approved by the local ethics committee.

220 patients between 5-15 ages who have URTI were included to the study. Informed consent was obtained from parents or legal guardian of participants. Patients who were taking antibiotics before evaluation and who have immune deficiency were excluded.

Age, gender, signs and symptoms of the patients were recorded after a detailed physical examination by a pediatrist. These signs and symptoms were chosen from the previous studies which aimed to differ bacterial and nonbacterial URTI by clinical scoring. ${ }^{7-9}$ Same physician obtained blood samples and swab of throat (Table 1).

Table 1. Signs and symptoms which were chosen from the previous studies about URTI

Suspicion of Bacterial URTI

Suspicion of Viral URTI

\begin{tabular}{|c|c|c|c|}
\hline \multirow[b]{2}{*}{ Symptoms } & \multicolumn{2}{|c|}{ Suspicion of Bacterial URTI } & \multirow{2}{*}{$\begin{array}{l}\quad \text { Suspicion of Viral URTI } \\
\text { Pharyngeal erythema } \\
\text { Tonsil hypertrophy } \\
\text { Painful anterior servical LAP* } \\
\text { Pharyngeal exuda (yellow) } \\
\text { Palatal petechia }\end{array}$} \\
\hline & $\begin{array}{l}\text { Sore throat } \\
\text { Fever }\left(38^{\circ} \mathrm{C}, \text { tympanic }\right) \\
\text { Swallowing difficulty } \\
\text { Malaise }\end{array}$ & $\begin{array}{l}\text { Sudden onset } \\
\text { Headache } \\
\text { Abdominal pain } \\
\text { Nausea, vomiting }\end{array}$ & \\
\hline Signs & $\begin{array}{l}\text { Halitosis } \\
\text { Myalgia } \\
\text { Coughing } \\
\text { Arthralgia } \\
\text { Nasal discharge }\end{array}$ & $\begin{array}{l}\text { Hoarseness } \\
\text { Sneeze } \\
\text { Diarrhea } \\
\text { Previous cold }\end{array}$ & $\begin{array}{l}\text { Conjonctivitis } \\
\text { Pharyngeal exuda (gray-white) } \\
\text { Minor painful LAP* } \\
\text { Pharyngeal ulcer } \\
\text { Widespread LAP* }\end{array}$ \\
\hline
\end{tabular}

*Lymphadenopathy

Throat cultures were obtained by microbiology technicians at pediatrics outpatient clinics and by pediatists at pediatric emergency room from posterior wall of tonsil and pharynx with sterile swab sticks and were reached to laboratory in transport nutrient. Specimens were applied to $\% 5$ sheep blood Brain-Heart agar plates. After a one night incubation, identification of bacteries were done with bacitracin 
(0.04 mcg) ve Maldi-tof MS (Matrix Assisted Laser Desorption/Ionization Time of Flight Mass Spektrometry) according to colony morphologies, beta hemolysis and gram positive/negative situations. Results of throat cultures were recorded.

Statistical Analysis: Data were analyzed by SPSS 19.0 for Windows (SPSS, Inc, Chicago, IL). Descriptive methods (frequency, percentage, mean, standard deviation) were used to analyze data. The Man-Whitney U test was used for comparison of data. A $p$ value less than 0.05 was considered as statistically significant.

\section{RESULTS}

Nighty-nine (45\%) of patients were female, 121 were (55\%) male. Mean age was $9.12 \pm 3.07$ years. Throat cultures were positive at 93 patients $(42 \%)$. GABHS were present at 56 of these (25.4\%). Most common symptoms and signs on admission were fever, malaise, sore throat and tonsillar hypertrophy, pharyngeal eritem. Fever, tonsillar hypertrophy, yellow pharyngeal exude, painful anterior cervical lymphadenopathy (LAP) and absence of cough were significantly higher in culture positive patients (Table 2).

Table 2. Relation of symptom and signs with throat culture results

\begin{tabular}{|c|c|c|c|}
\hline & \multicolumn{2}{|c|}{ Throat culture result } & \multirow[b]{2}{*}{$\chi^{2}$} \\
\hline & Positive, n (\%) & Negative, n (\%) & \\
\hline \multicolumn{4}{|l|}{ SYMPTOMS } \\
\hline Sore Throat & 88 (94.6) & $5(5.4)$ & 2.69 \\
\hline Fever $\left(>38^{\circ} \mathrm{C}\right)$ & $81(88.2)$ & $12(11.8)$ & 8.05 \\
\hline Swallowing Difficulty & 75 (80.6) & $18(19.4)$ & 1.39 \\
\hline Malaise & $70(75.3)$ & $23(24.7)$ & 1.06 \\
\hline Sudden Onset & $61(65.6)$ & $32(34.4)$ & 0.75 \\
\hline Headache & $58(62.4)$ & $35(\% 37.6)$ & 1.42 \\
\hline Halitosis & $45(48.4)$ & $48(51.6)$ & 0.01 \\
\hline Myalgia & $43(46.2)$ & $50(53.8)$ & 0.07 \\
\hline Absence of Cough & $38(40.9)$ & $55(59.1)$ & 8.41 \\
\hline Arthralgia & $35(37.6)$ & $58(62.4)$ & 1.15 \\
\hline Abdominal Pain & $30(32.3)$ & $63(67.7)$ & 0.06 \\
\hline Nasal Discharge & $26(28)$ & $67(72)$ & 1.66 \\
\hline Nausea-vomiting & $19(20.4)$ & $74(79.6)$ & 0.91 \\
\hline Hoarseness & $12(12.9)$ & $81(87.1)$ & 0.01 \\
\hline Sneeze & $10(10.8)$ & $83(89.2)$ & 2.72 \\
\hline Diarrhea & $5(5.4)$ & $88(94.6)$ & 2.69 \\
\hline \multicolumn{4}{|l|}{ SIGNS } \\
\hline Conjunctivitis & $9(9.7)$ & $84(90.3)$ & 0.45 \\
\hline Pharyngeal Erythema & $87(93.5)$ & $6(6.5)$ & 0.97 \\
\hline Tonsillar Hypertrophy & $82(88.2)$ & 11(11.8) & 3.84 \\
\hline Painful Anterior Servical LAP & $45(48.4)$ & $48(51.6)$ & 12.69 \\
\hline Pharyngeal Exuda (yellow) & $30(32.3)$ & $63(67.7)$ & 11.37 \\
\hline Pharyngeal Exuda (gray-white) & $12(12.9)$ & $81(87.1)$ & 1.41 \\
\hline Petechia on Hard Palate & $3(3.2)$ & $90(96.8)$ & 1.78 \\
\hline Widespread LAP* & $2(2.2)$ & $91(97.8)$ & 0.10 \\
\hline
\end{tabular}

LAP; Lymphadenopathy

$\chi 2$; Chi square 
Swallowing difficulty, abdominal pain, headache, absence of conjunctivitis, absence of hoarseness, absence of diarrhea were evaluated for sensitivity, specifity, positive predictive value, negative predictive value. Results for fever, painful anterior servical LAP, absence of coughing and tonsillar hypertrophy were significant (Table 3).

Table 3. Value of symptoms and signs in patients whose throat cultures were positive

\begin{tabular}{|c|c|c|c|c|c|}
\hline & Sensitivity (\%) & Specifity (\%) & PPV (\%) & NPV (\%) & $\mathbf{p}$ \\
\hline Fever $\left(>38^{\circ} \mathrm{C}\right.$, tympanic $)$ & 88.17 & 27.55 & 47.12 & 76.08 & 0.05 \\
\hline $\begin{array}{l}\text { Painful Anterior } \\
\text { Servical LAP }\end{array}$ & 48.38 & 74.80 & 58.44 & 66.43 & 0.010 \\
\hline Absence of Cough & 40.86 & 39.37 & 33.04 & 47.61 & 0.004 \\
\hline $\begin{array}{l}\text { Tonsillar Hypertrophy } \\
\text { and Exuda }\end{array}$ & 88.17 & 22.04 & 45.30 & 71.79 & 0.049 \\
\hline Swallowing Difficulty & 80.64 & 25.19 & 44.11 & 64 & 0.307 \\
\hline Abdominal Pain & 32.25 & 69.29 & 43.7 & 58.27 & 0.800 \\
\hline Headache & 62.36 & 45.66 & 42.58 & 64.8 & 0.233 \\
\hline Absence of Conjonctivitis & 9.67 & 87.40 & 36 & 56.92 & 0.500 \\
\hline Absence of Hoarseness & 12.90 & 87.40 & 42.85 & 57.81 & 0.232 \\
\hline Absence of Diarrhea & 5.37 & 88.18 & 25 & 56 & 0.103 \\
\hline
\end{tabular}

LAP; Lymphadenopathy

PPV; Positive Predictive Value

NPV; Negative Predictive Value

A scoring system was created with these parameters (Table 4). Patients were scored with this system retrospectively. Total scores evaluated with ROC analysis. The area under curve was 0.557 , cut point was 6.5 . Thus, our scoring system may be useful when total score is $\geq 7$ with $62.1 \%$ sensitivity and $55 \%$ specifity (Table 5 ). 
Table 4. Scoring system

\begin{tabular}{lc}
\multicolumn{1}{c}{ CRITERIA } & SCORES \\
\hline Fever $\left(>38^{\circ} \mathrm{C}\right)$ & 1 \\
Absence of Cough & 1 \\
Painful Anterior & 1 \\
Servical LAP & 1 \\
Tonsillar Hypertrophy & 1 \\
Swallowing Difficulty & 1 \\
Abdominal Pain & 1 \\
Headache & 1 \\
Absence of Conjonctivitis & 1 \\
Absence of Hoarseness & 1 \\
Absence of Diarrhea &
\end{tabular}

LAP; Lymphadenopathy

Table 5. Relation between total score and throat culture results

\begin{tabular}{lcccccccc}
\hline $\begin{array}{l}\text { THROAT } \\
\text { CULTURE }\end{array}$ & $\begin{array}{c}\mathbf{2} \\
\text { Points }\end{array}$ & $\begin{array}{c}\mathbf{3} \\
\text { Points }\end{array}$ & $\begin{array}{c}\mathbf{4} \\
\text { Point } \\
\text { s }\end{array}$ & $\begin{array}{c}\mathbf{5} \\
\text { Points }\end{array}$ & $\begin{array}{c}\mathbf{6} \\
\text { Points }\end{array}$ & $\begin{array}{c}\mathbf{7} \\
\text { Points }\end{array}$ & $\begin{array}{c}\mathbf{8} \\
\text { Points }\end{array}$ & $\begin{array}{c}\mathbf{9} \\
\text { Points }\end{array}$ \\
\hline Positive n (\%) & $0(0)$ & $1(1.1)$ & $6(6.5)$ & $2(2.2)$ & $19(20.4)$ & $21(22.6)$ & $20(21.5)$ & $18(19.4)$ \\
Negative n $(\%)$ & $1(0.8)$ & $8(6.3)$ & $8(6.3)$ & $20(15.7)$ & $27(21.3)$ & $32(25.2)$ & $17(13.4)$ & $11(8.7)$ \\
Total n $(\%)$ & $1(0.5)$ & $9(4.1)$ & $14(6.4)$ & $22(10)$ & $46(20.9)$ & $53(24.1)$ & $37(16.8)$ & $29(13.2)$ \\
\hline
\end{tabular}

\section{DISCUSSION}

Upper respiratory tract infections are the most common community-acquired infections among children. ${ }^{10}$ School absenteeism, morbidity, complications and cost due to illness and treatment period actually make these infections an important social problem. ${ }^{11}$ In a study, which evaluated parameters such as duration of illness, loss of work, cost of treatment, the total cost of a tonsillitis was estimated to be 385 US dollars. ${ }^{12}$

Viral agents are the most common cause of URTI in children. ${ }^{3,4}$ The most common cause of bacterial URTI is GABHS (13-31.5\%). ${ }^{13-}$

${ }^{15}$ In our study, bacteria were growth in throat cultures in 93 patients $(42 \%)$ whereas $25.4 \%$ of them were GABHS in accordance with the literature.

When treatment is planned for patients with URTI, trying to distinct bacterial and viral cases, considering GABHS in first priority for bacterial URTI and considering antibiotics effective for GABHS should increase success of treatment. The early diagnose and treatment of tonsillopharyngitis caused by GABHS is important in preventing serious complications in the childhood, such as acute rheumatic fever and acute glomerulonephritis. Therefore, there are many scoring system studies in literature review about the early diagnosis and treatment of GABHS tonsillopharyngitis. ${ }^{7,8}$

Breese scoring system was developed for streptococcal tonsillopharyngitis with a study of 20,000 children at 1977 , in which age, leukocyte count, fever, sore throat, coughing, headache, abnormal pharyngeal appearance and pathological cervical lymph node were questioned. In this system, positivity of throat culture was reported to be $77.6 \%$ when the score was above $30 .{ }^{16}$ In one study, the sensitivity, specificity, positive and negative predictive values of this scoring system were $25 \%, 91 \%, 37.5 \%$ and $85 \%$ in children younger than 3 years, $76 \%, 67 \%, 51 \%$ and $86 \%$ in children older than 3 years. ${ }^{17}$

In a meta-analysis study conducted in 2012, 16 different scoring studies were examined. Eleven of these were in developed countries and 5 were in developing countries. These studies include a total of 17 variables but most frequent variables were LAP, pharyngeal exudation, age, fever, coughing. ${ }^{18}$ There were 10,523 children with an average age of 7 years. It has been stated that the different results of studies in different countries may be due to the subjective nature of the symptoms in children and it is stated that it is very difficult for children to develop a scoring system. McIsaac's study was not found useful in making clinical decision (specificity 4-14\%). The best study in clinical decision making was seen as Joachim's study (95\% confidence interval). But this study is thought to be impractical 
because there were too many (9) parameters. However, it was shown that antibiotic prescription reduced 29-48\% in scoring studies that uses symptoms and signs related to URTI. ${ }^{7,8,19}$

In our study, we aimed to develop a scoring system by using parameters that were significantly frequent in children with positive throat cultures (fever, tonsillar hypertrophy, yellow pharyngeal exudate, painful anterior cervical LAP and absence of cough) and parameters that cause strong suspicion for bacterial infection (swallowing difficulty, abdominal pain, headache, absence of conjunctivitis, absence of diarrhea), we tried to develop a scoring system.

It was observed that the scoring system we developed could help to define a bacterial URI when the total score is 7 or higher. However, this system has not been effective scoring system due to low sensitivity (62.1\%) and specificity (55\%). There are many studies for scoring system about URTI in literature, but there is still not an effective scoring system in the practice. This suggests the difficulty of developing a scoring system for URTI, probably because the symptoms are subjective in children.

The major limitation of this study was the method in defining score points. In the previous studies ${ }^{5-7}$, clinical signs and symptoms associated with a positive culture result were entered into a backward stepwise multiple logistic regression model and those that were independently associated with being more likely to have a throat culture positive for GAS were weighted equally and assigned a score of 1 point. The failure of these previous studies on developing an effective clinical scoring system forced us to try a different way. We defined score 1 for some signs and symptoms according to these previous studies (fever, absence of cough, painful anterior cervical LAP, tonsillar hypertrophy) and some others according to our expectation for being related with bacterial URTI (swallowing difficulty, abdominal pain, headache, absence of conjunctivitis, absence of hoarseness, absence of diarrhea).

In conclusion, URTI is the most common infectious disease of children and it is very important to perform bacterial-viral discrimination with evaluating only signs and symptoms without a need for laboratory screening. For this purpose, there is a need for an internationally recognized clinical scoring system. However, it is difficult to develop an effective scoring system due to the subjective nature of the symptoms and different ethnic backgrounds. Larger multi-centered studies are needed to develop an effective scoring system for URTI in children.

\section{Conflict of interest: None \\ Financial disclosure: None}

\section{REFERENCES}

1. Tenover FC, Hughes JM. The challenge of emerging infectious diseases. Development and spread of multiply-resistant bacterial pathogens. JAMA 1996;275:300-4.

2. Brook I. Microbiology of common infections in the upper respiratory tract. Prim Care 1998; 25(3): 633-48.

3.Çocuk Enfeksiyon Hastalıkları Derneği: Çocuklarda Üst Solunum Yolu Enfeksiyonları. İstanbul, Çocuk Enfeksiyon Hastalıkları Derneği Yayınları: 1-19. 3-7, 2002

4.Garry R. Upper respiratory tract infections in family practice. Pediatric Infect Dis 1998; 17: 73-8.

5.Bisno AL, Gerber MA, Gwaltney JM, et al. Diagnosis and management of group A streptococcal pharyngitis: a practice guideline. Infectious Diseases Society of America. Clin Infect Dis 1997; 25 (3): 574.

6. Del Mar C, Glasziou P, Lowe JB, et al. Addressing antibiotic resistance-focusing on acute respiratory infections in primary care. Aust Fam Physician. 2012;41(11):839- 40.

7.McIsaac WJ, White D, Tannenbaum D, et al. A clinical score to reduce unnecessary antibiotic use in patients with sore throat. CMAJ 1998; 158: 75-83.

8.Joachim L, Campos D Jr, Smeesters PR. Pragmatic scoring system for pharyngitis in low-resource settings. Pediatrics 2010; 126: 608-14.

9.Dagnelie CF, Bartelink ML, Van der Graaf Y, et al. Towards a better diagnosis of throat infections (with group A beta-haemolytic streptococcus) in general practice. Br J Gen Pract 1998; 48: 959-62.

10. Hayden GF, Turner RB. Acute pharyngitis. Kleigman R.Jenson H, Behrman R, Stanton B, (eds). Nelson Texbook of Pediatrics Philadelphia, Saunders; p: 1752-4. 2007

11.Perry M, Whyte A. Immunology of the tonsils. Immunol Today 1998; 19: 414-21.

12.K Roos, R Claesson, U Persson, et al. The economic cost of a streptococcal tonsillitis episode. Scand J Prim Health Care 1995; 13(4): 257-60.

13.Martin JM, Green M, Bardabora MT, et al. Group A Streptococci Among School Aged Children: Clinical Characteristics and Carrier State. Pediatrics 2004; 114: 1212-9.

14.Brook I, Gober AE. Increased recovery of Moraxella catarrhalis and Haemophilus influenzae in association with group A (beta)haemolytic streptococci in healthy children and those with pharyngo-tonsillitis. J Med Microbiol 2006; 55: 989-92.

16.Stingu CS, Turku T, Dimitriu S, et al. The impact of a sore throat score on clinical management of streptococcal angina. Rev Med Chir Soc Med 2005; 109: 136-9.

14.Breese BB. A simple scorecard for the tentative diagnosis of streptococcal pharyngitis. Am J Dis Child 1977; 131: 514-17.

17.Ulukol B, Günlemez A, Aysev D, et al. Alternative diagnostic method for streptococcal pharyngitis: Breese scoring system. Turk J Pediatr 2000; 42: 96-100.

18.Le Marechal F, Martinot A, Duhamel A, et al. Streptococcal pharyngitis in children: a meta-analysis of clinical decision rules and their clinical variables. BMJ Open 2013; 3: e001482. doi: 10.1136/bmjopen-001482.

19.Dobbs F. A scoring system for predicting group A streptococcal throat infection. Br J Gen Pract 1996; 46: 461-4. 